\title{
Friendship, Philology and Deceit in the Margins of a Greek Manuscript of John Chrysostom Copied for Erasmus: Reconstructing the Story of MS Wolfenbüttel, Herzog August Bibliothek, Gud. gr. $2^{\circ} 10$
}

\author{
Sam Kennerley ${ }^{1}$ \\ Published online: 4 December 2019 \\ (c) The Author(s) 2019
}

\section{Introduction}

Of Erasmus's many scholarly controversies, his exchange with Martin Luther about the freedom of the will is perhaps the best known. The outlines of this controversy can be quickly drawn. Erasmus and Luther had never seen eye to eye, but coldness turned to conflict in September 1524, when Erasmus's defence of the freedom of the will — the De libero arbitrio — was printed in Basel. Luther mockingly thanked Erasmus for an opportunity to express his views on this topic, responding with his De servo arbitrio (On the Bondage of the Will) in December 1525. The cycle of tract and counter-tract turned again with Erasmus's two responses to Luther, the Hyperaspistes I of February 1526 and Hyperaspistes II printed a year later. ${ }^{1}$

Accounts of Erasmus's approach to free will have typically ended here, leaving him locked in a defence of free will against Luther. But in a recent book, Greta Kroeker proposed that Erasmus's views on free will continued to evolve in later works, such as the revised editions of his Annotations to the New Testament printed in 1527 and 1535. Indeed, Kroeker argued that not only did Erasmus's views continue to evolve, but that they evolved in a direction that gave increasing room to the working of grace over free will. These 'Lutheranizing changes' were partly sparked by Erasmus's contact with patristic writings on the letters of Paul, among them the Greek Church Father John Chrysostom's (c. 350-407) Homilies on Romans. ${ }^{2}$ Chrysostom's impact on Erasmus's thought in the late 1520s is evident when we look at the Dutchman's Annotations on the letter to the Romans. Chrysostom is cited there

\footnotetext{
${ }^{1}$ C. Trinkaus, 'Introduction', in Controversies: De libero arbitrio $\triangle I A T P I B H$ sive collatio; Hyperaspistes 1, ed. C. Trinkaus, Collected Works of Erasmus, 76, Toronto, 1999, pp. xlvii-1xxxiv.

${ }^{2}$ G. G. Kroeker, Erasmus in the Footsteps of Paul: A Pauline Theologian, Toronto, 2011, p. 38.

Sam Kennerley

sjk76@cam.ac.uk

1 Peterhouse, Cambridge CB2 1RD, UK
} 
almost 200 times, but only in or after the 1527 edition of the Annotations. ${ }^{3}$ Moreover, these citations were significant in a qualitative as well as a quantitative sense. As we'll explore in greater detail below, Chrysostom's Homilies on Romans were central to Erasmus's new interpretation of free will and grace in his exposition of passages such as Romans 5:1 and 11:6.

The puzzle of Erasmus's changing theology of free will and grace, and Chrysostom's place in it, has therefore been partially assembled. Nonetheless, one significant piece has been left out. The critical apparatus of the modern edition of Erasmus's Annotations on Romans frequently notes that Erasmus's readings of Chrysostom's Homilies on Romans do not match the Migne edition of these homilies. That a sixteenth-century scholar's text of Chrysostom's Homilies on Romans should fail to match that of a nineteenth-century edition need not be too surprising, ${ }^{4}$ and if evidence for Erasmus's text of Chrysostom no longer existed, the question would have to be left there. But what we can ask of these textual variants changes once we realize that evidence for Erasmus's text still exists. This process of identification begins, as it often does with Erasmus, in the Dutchman's letters.

\section{Erasmus and Chrysostom's Homilies on Romans}

On 5 December 1526, Erasmus wrote a letter to Theobald Fettich. Part of it read:

I am told that where you live there is a rare collection of old manuscripts. The strong support that you and the honourable Wolfgang von Affenstein give to the cause of learning has long been known to me both from the voice of hearsay and from my correspondence with learned friends, and I know also of the generosity that both of you show towards men of letters. It is for this reason that Hieronymus Froben [son of Erasmus's favourite printer, Johann Froben] did not hesitate to visit you, and I have not scrupled to address you by letter. My instinct tells me that our temerity (or should I call it our confidence in your kindness?) will turn out well for us. ${ }^{5}$

Theobald Fettich is not a well-known name in the sixteenth-century republic of letters. He was, however, in a position useful to Erasmus. Fettich was the physician of Wolfgang von Affenstein, a courtier and administrator who also served as custodian of the huge library assembled by Johann von Dalberg, bishop of Worms between 1482 and 1503, at Ladenburg castle near Heidelberg. ${ }^{6}$ This library was in a ruinous

\footnotetext{
${ }^{3}$ P. F. Hovingh, 'Introduction', in Erasmus, Opera omnia ... Ordinis sexti, tomus septimus, ed. P. F. Hovingh, Leiden, 2012, p. 5.

${ }^{4}$ For observations about the silent but substantial changes between sixteenth-century texts and modern editions, see also M. M. Gorman, 'Anianus of Celeda and the Latin Translations of John Chrysostom's Homilies on the Gospel of Matthew', Revue Bénédictine, 122, 2012, pp. 100-124.

5 Letter 1767: Erasmus to Theobald Fettich, Basel, 5 December 1526, in The Correspondence of Erasmus: Letters 1658 to 1801, transl. A. Dalzell, Collected Works of Erasmus, 12, Toronto, 2003, p. 407.

${ }^{6}$ P. Walter, "Inter nostrae tempestatis pontifices facile doctissimus". Der Wormser Bischof Johannes von Dalberg und der Humanismus', in Der Wormser Bischof Johann von Dalberg (1482-1503) und seine Zeit, ed. G. Bönnen and B. Keilmann, Mainz, 2005, pp. 121-40.
} 
condition by Erasmus's time, but von Affenstein was willing to let scholars with the right credentials explore its contents. Under Fettich's patronage, another scholar active in Basel, Johannes Sichardus, had gained access to Dalberg's library and found there a manuscript of Caelius Aurelianus that he would use for his 1529 edition of this author. Sichardus's find perhaps prompted Erasmus to send Hieronymus Froben to the Ladenburg library, ${ }^{7}$ and the visit turned out to be no less successful than Erasmus had hoped in his letter to Fettich. On $28^{\text {th }}$ December 1526, von Affenstein wrote to Erasmus that he had gladly admitted Hieronymus Froben to Dalberg's library, and permitted Hieronymus to borrow whatever manuscripts he wanted, on the condition that they be returned. ${ }^{8}$

One of the authors that Erasmus was searching for at this time was Chrysostom. Between October 1525 and May 1527, Erasmus acquired a significant number of Greek copies of Chrysostom's works, many of them of his homilies on Paul. ${ }^{9}$ And although von Affenstein's letter does not mention it, we know that Hieronymus Froben found a Greek manuscript of Chrysostom in Dalberg's library. In a letter that we will return to later, the French priest and courtier Germain de Brie remarked that Erasmus had 'managed to find in the Ladenburg library the golden, and truly divine commentaries of Chrysostom on the letter of Paul to the Romans'. ${ }^{10}$ De Brie further noted that Erasmus had had this manuscript of Chrysostom's Homilies on Romans copied, ${ }^{11}$ a point suggested by Erasmus's reference in a letter of 5 September 1530 that he possessed 'twin' copies of this work. ${ }^{12}$

From this learned correspondence, we can gather that in December 1526 Hieronymus Froben found a Greek manuscript of Chrysostom's Homilies on Romans in the library of Johann von Dalberg, and that Erasmus had another copy of this text made before 1530 . However, enquiries have not yet been made about whether the manuscripts of Chrysostom's Homilies on Romans mentioned in Erasmus's correspondence survive today. This is despite the fact that the second volume of the Codices Chrysostomici Graeci, the monumental census of Greek manuscripts of Chrysostom, records a text of significant interest to this story: MS Wolfenbüttel, Herzog

\footnotetext{
7 Letter 1767 (n. 5 above), p. 406.

8 Letter 1774: Wolfgang von Affenstein to Erasmus, Ladenburg, 28 December 1526, in Correspondence of Erasmus: Letters 1658 to 1801 (n. 5 above), pp. 425-6.

9 For one extant manuscript of Chrysostom discovered for Erasmus in this period (but not of homilies on Paul), MS Oxford, Bodleian Library, Auct. E. 1. 13, see W. Lackner, 'Erasmus von Rotterdam als Editor und Übersetzer des Johannes Chrysostomus', Jahrbuch der Österreichischen Byzantinistik, 37, 1986, pp. 293-311. For other manuscripts of Chrysostom found in this period, see Letter 1675: Erasmus to Reginald Pole, Basel, 8 March 1526, in Correspondence of Erasmus: Letters 1658 to 1801 (n. 5 above), p. 74; Letter 1736: Erasmus to Germain de Brie, Basel, [c. 27 August 1526]', ibid., pp. 285-6; Letter 1817: Germain de Brie to Erasmus, Paris, 10 May 1527, in The Correspondence of Erasmus: Letters 1802 to 1925, transl. C. Fantazzi, Collected Works of Erasmus, 13, Toronto, 2010, pp. 112-13.

10 John Chrysostom, In Epistolam Divi Pauli ad Romanos Homiliae octo priores, Basel, 1533, p. 5: '[E] bibliotheca Ladenburgensi Germanica eruere potuit Chrysostomi aurea, ac uere diuina in diui Pauli ad Romanos epistolam commentaria.'

11 Ibid.: '[Erasmus] ea statim commentaria describenda, et ad me mittenda curauerit'.

12 Letter 2379: Erasmus to Germain de Brie, Freiburg, 5 September 1530, in Desiderius Erasmus, Opus epistolarum ..., ed. P. S. Allen et al., 12 vols, Oxford, 1906-58, IX, p. 31: '[C]erte commentariorum in Epistolam ad Romanos geminum habebam exemplar.'
} 
August Bibliothek, Gud. gr. $2^{\circ} 10$, a Greek exemplar of Chrysostom's Homilies on Romans, copied for Erasmus in 1528 by the Dutchman's secretary, Nicholas Kan. ${ }^{13}$

The brief entry about this manuscript in Codices Chrysostomici Graeci does not lay out the proofs for this provenance. There are, as such, some initial difficulties in accepting the attribution. This is the only Greek manuscript that Kan is known to have copied for Erasmus, a fact that is surprising given that the size of the manuscript (256 folios) suggests that Kan ought to have been able to copy other texts, and inconvenient in that it makes verification of the manuscript's provenance by comparison with other examples of Kan's Greek hand impossible. However, the provenance of this manuscript noted in Codices Chrysostomici Graeci rests on solid grounds. Between $5^{\mathrm{v}}$ and $6^{\mathrm{r}}$ of the manuscript, a small slip of paper is present that reads 'Per me Nicolaum Cannium Amsterodamum' [[Written] by me, Nicholas Kan of Amsterdam]. At the very end of the manuscript, there is also a folio signed by Kan and dated by him to $1528 .{ }^{14}$ Neither of these sources are convincing alone — both could have been added to the manuscript at a later date — but they are corroborated by further internal evidence in the manuscript. Between folios $168^{\mathrm{r}}$ and $169^{\mathrm{r}} \mathrm{Kan}$ 's seal is present and accompanied the initials N. C. (for Nicolaus Cannius). The paper of the manuscript is also of Basel manufacture, dating from the 1520s. ${ }^{15}$

Signed and dated by a known secretary of Erasmus, and copied on paper made during his residence in Basel: everything indicates that the Wolfenbüttel manuscript of Chrysostom's Homilies on Romans is the copy made for Erasmus from the exemplar found in Johann von Dalberg's library. Through this discovery, we are furnished with basic details about this manuscript not mentioned in Erasmus's correspondence. We now know that its scribe was Nicholas Kan, and that it was copied in 1528. But the manuscript is informative in ways that extend beyond the textual history of Chrysostom's Homilies on Romans.

At this point, we can return to the problem with which we started this article. It was observed earlier that Erasmus's quotes of the Greek of Chrysostom's Homilies on Romans do not always correspond with the Migne edition. Let's take a look at one example of this dissonance, in a passage that was highlighted by Kroeker as an example of Chrysostom's influence on Erasmus's changing theology of free will and grace in the 1527 Annotations. ${ }^{16}$ This passage is within Erasmus's commentary on the text of Romans 11:6:

The Greek codices have somewhat more here than do the Latin. For they provide a repetition in the 'works that are not works' expression in the following

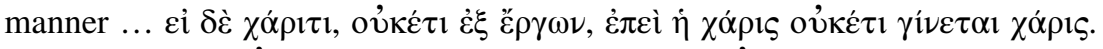

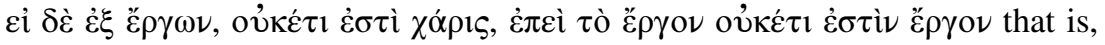
'but if through grace; no longer from works, inasmuch as grace is no longer grace; but if from works, it is no longer grace, inasmuch as work is no longer

${ }^{13}$ Codices Germaniae, ed. R. E. Carter, Codices Chrysostomici Graeci, 2, Paris, 1968, p. 83.

${ }^{14}$ MS Wolfenbüttel, Herzog August Bibliothek, Gud. gr. $2^{\mathrm{o}}$ 10, fol. $260^{\mathrm{r}}$ : 'Per me Nicolaum Cannium familiarem D[omi]ni d. Erasmi Rotterodami. An. D[omi]ni MDXXVIII'.

${ }^{15}$ See Griechische Handschriften und Aldinen, Wolfenbüttel, 1978, p. 102.

${ }^{16}$ Kroeker, Erasmus in the Footsteps (n. 2 above), pp. 78-80. 
work'... But since I do not find this addition in Origen, I am somewhat doubtful that it is the true reading, especially since Chrysostom in expounding this

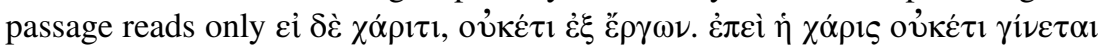
$\chi \alpha$ ópı. He adds nothing to these words. ${ }^{17}$

Erasmus therefore preferred a pared-down reading of Romans 11:6 that unambiguously stressed the importance of grace over works. Surprisingly for a scholar associated with a preference for the Greek Bible over the Vulgate, Erasmus here favoured the Latin tradition of this verse, but still adduced Origen, and from 1527 Chrysostom, as Greek witnesses to his preferred reading. However, the Migne edition of

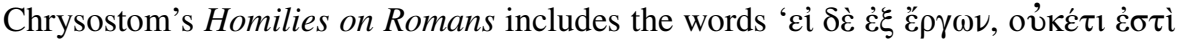

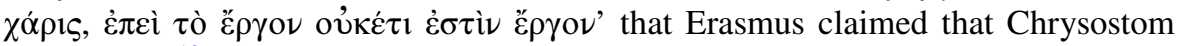
had omitted. ${ }^{18}$ If we assume that Erasmus used the same text as printed in the Migne edition, his citation of Chrysostom on Romans 11:6 is puzzling, even dishonest. But these charges are dismissed on consultation of the Wolfenbüttel manuscript of Chrysostom's Homilies on Romans. There, Chrysostom omits precisely the words

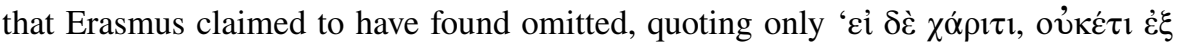

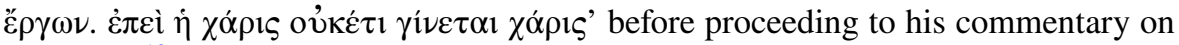
this verse. ${ }^{19}$

Examples in which Erasmus's quotes of Chrysostom's Homilies on Romans exactly match the Wolfenbüttel manuscript while differing from the edition of Migne could be multiplied. Now, as we saw earlier, the manuscript of Chrysostom's Homilies on Romans that was discovered at the Ladenburg library no longer survives. This was the manuscript that Erasmus would have used when preparing his readings of Chrysostom for the 1527 edition of his Annotations. Nonetheless, the loss of this work does not mean that Erasmus's text of Chrysostom's Homilies on Romans is irrecoverable. The close correspondence between Wolfenbüttel manuscript and Erasmus's citations of the Homilies on Romans suggests that Nicholas Kan copied the Wolfenbüttel manuscript sufficiently well to represent the readings that Erasmus found in his now-lost exemplar. The Wolfenbüttel manuscript is therefore the best witness that we now have to the text of Chrysostom's Homilies on Romans used by Erasmus in 1527, and any future study of Erasmus's Greek text of these homilies must therefore begin with it, rather than with Migne or other editions.

\section{Plans for a Latin Version of Chrysostom's Homilies on Romans}

Its nature as the best surviving witness to Erasmus's text of Chrysostom's Homilies on Romans is one reason why the Wolfenbüttel manuscript merits our attention. However, its significance extends into another realm, too. The Wolfenbüttel manuscript is covered with annotations, most of them in a single sixteenth-century hand.

\footnotetext{
17 Desiderius Erasmus, Annotations on Romans, ed. R. D. Sider and transl. J. B. Payne et al., Collected Works of Erasmus, 56, Toronto, 1994, p. 295

18 Patrologiae cursus completus ... series Graeca prior, ed. J.-P. Migne, LX, Paris, 1862, col. 578.

19 MS Wolfenbüttel, Herzog August Bibliothek, Gud. gr. $2^{\circ} 10$, fol. 179v
} 
This hand has not been identified, ${ }^{20}$ and the process of doing so obliges us to step once more into Erasmus's letters.

References to a Greek copy of Chrysostom's Homilies on Romans frequently appear in Erasmus's correspondence as part of preparations for the 1530 Froben edition of Chrysostom's complete works. ${ }^{21}$ In November 1529, Erasmus sent a Greek manuscript of the Homilies on Romans to the Netherlands in the hope that scholars there could be persuaded to translate them into Latin. ${ }^{22}$ His first choice was for the homilies to be translated by contacts in Louvain. Failing that, the manuscript was to be passed to Levinus Ammonius, a Carthusian monk of Ghent who had already translated Chrysostom's De fato et de providentia Dei. ${ }^{23}$ Despite some confusion about the whereabouts of the manuscript, ${ }^{24}$ Erasmus was sufficiently reassured about this project to write in March 1530 that the translation of Chrysostom's Homilies on Romans was being undertaken by scholars at Louvain. ${ }^{25}$ These hopes were however dashed in a letter from the Louvain scholar Conrad Goclenius, datable to 14 July 1530. Goclenius wrote that:

The bearer of this letter ... should discuss with you whether he should go on to Basel to deliver the commentaries on Chrysostom that Nicolaus Episcopius left with me, not because I had undertaken the task of translation, but so that I could discuss the matter with Levinus Ammonius, Frans von Cranevelt, and Nicolaus Clenardus, who teaches Greek and Hebrew here privately. He preferred that I do the translation, but I was prevented by business, which keeps overtaking me like a succession of hurricanes and time after time interrupts the progress of my work. Then some allowance had to be made for my health, which has not yet sufficiently recovered from the recent plague. But since no one could be induced to do the work, I am returning the book at my own expense, so that Froben will have no reason to find fault. ${ }^{26}$

The Greek exemplar was ultimately sent back from Louvain, although whether to Erasmus in Freiburg or Froben in Basel is not clear. ${ }^{27}$ A translation that Erasmus had assumed was under way had therefore never even been started. Erasmus expressed his indignation at this fact to other correspondents, labelling the Louvain scholars

\footnotetext{
${ }^{20}$ It is referred to as a 'fremder Hand' in Griechische Handschriften und Aldinen (n. 15 above), pp. 101-3. Like the authors of this entry, I do not, however, rule out that there are at least two other hands at work in this manuscript.

21 John Chrysostom, Opera, quae hactenus versa sunt omnia, 4 vols, Basel, 1530.

22 For this date, see Letter 2258: Levinus Ammonius to Erasmus, St Maartensbos, 17 January 1530, in The Correspondence of Erasmus: Letters 2204 to 2356, transl. A. Dalzell, Collected Works of Erasmus, 16, Toronto, 2015, p. 139, n. 4.

23 John Chrysostom, Sermo, de providentia Dei, et fato, Antwerp, 1527.

24 See Letter 2286: Erasmus to Erasmus Schets, Freiburg, 19 March 1530, in Erasmus, Opus epistolarum (n. 12 above), VIII, pp. 385-6.

25 Letter 2291: Erasmus to Germain de Brie, Freiburg, 27 March 1530, ibid., p. 391.

26 Letter 2352: Conradus Goclenius to Erasmus, Louvain, 14 July [1530], in Correspondence of Erasmus: Letters 2204 to 2356 (n. 22 above), p. 396.

27 Letter 2379: Erasmus to Germain de Brie, Freiburg, 5 September 1530, in Erasmus, Opus epistolarum (n. 12 above), IX, p. 31.
} 
'men equal to the task, but ... more interested in enjoying themselves than doing a respectable job'. ${ }^{28}$ Erasmus soon found another translator to attempt the task of rendering Chrysostom's Homilies on Romans into Latin, however. On 8 November 1530, a Greek manuscript of these homilies was in the hands of Germain de Brie, then present at the court of King François I at Blois. ${ }^{29}$

Erasmus and Germain de Brie had long known one another. They had first met in 1508 in the printing shops of Venice, where de Brie wrote the poems that Erasmus placed at the head of the Aldine edition of his Adagiorum Chiliades. ${ }^{30}$ De Brie then left Venice for the households of French prelates and royalty, becoming secretary to Anne of Brittany in 1512, and building a name for himself among the intellectual circles of Paris. ${ }^{31}$ In the late 1520 s, the intermittent correspondence between Erasmus and de Brie intensified as they came into ever closer collaboration about editions of John Chrysostom, founded on mutual hostility towards translations of this Church Father produced by the leader of the Reformation in Basel, Johannes Oecolampadius. This friendship was further solidified when de Brie defended Erasmus's name in France after the Dutchman's ill-advised comments about the prince of French humanists, Guillaume Budé, in his Ciceronianus of $1528 .{ }^{32}$

By 1530, Germain de Brie was therefore Erasmus's closest French correspondent, as well as a poet and Hellenist of considerable stature in his own right. His career has however received little attention. ${ }^{33}$ This is partly a consequence of surviving source material. De Brie lived a life of rich and cultured ease, and refused to let deadlines dictate his work. ${ }^{34}$ In one relevant example, Erasmus asked de Brie translate Chrysostom's homily Comparatio regis et monachi (Comparison between a King and a Monk) for the 1530 Froben edition of this Church Father's works, but de Brie dispatched even this short piece only after the volume in which it was meant to appear had already gone to press. ${ }^{35}$ De Brie's surviving literary corpus is therefore rather limited. Marie-Madeleine de la Garanderie, the most active of de Brie's modern students, has assembled a list of extant works in print, to which can be added books from his library, and some manuscript material. ${ }^{36}$ This small body of texts has

\footnotetext{
${ }^{28}$ Letter 2379: Erasmus to Germain de Brie, Freiburg, 5 September 1530, in The Correspondence of Erasmus: Letters 2357 to 2471, transl. C. Fantazzi, Collected Works of Erasmus, 17, Toronto, 2016, p. 54.

29 De Brie's exact whereabouts are indicated in the introduction to Letter 2405: Germain de Brie to Erasmus, From the court [Blois], 8 November 1530, ibid., p. 126.

${ }^{30}$ Desiderius Erasmus, Adagiorum chiliades tres, ac centuriae fere totidem, Venice, 1508, sig.[B2. ${ }^{\mathrm{V}}$ ].

31 These biographical details are derived from M.-M. de la Garanderie, 'De Brie (Germain) (Brixius Germanus), (c. 1489-1538)', in Centuriae Latinae: Cent une figures humanistes de la Renaissance aux Lumières offertes à Jacques Chomarat, ed. C. Nativel, Geneva, 1997, pp. 305-8.

32 Ibid., p. 307.

33 In addition to de la Garanderie, 'De Brie' (n. 31 above), see ead., 'Germain de Brie', in Contemporaries of Erasmus, ed. P. G., Bietenholz and T. B. Deutscher, 3 vols, Toronto, 1985-87, I, pp. 200-202; and ead., Christianisme et lettres profanes: Essai sur l'Humanisme français (1515-1535) et sur la pensée de Guillaume Budé, 2nd ed., Paris, 1995, pp. 133-60.

34 Letter 2405, in Erasmus, Opus epistolarum (n. 12 above), IX, p. 83.

35 Letter 2291, ibid., VIII, p. 390.

36 De la Garanderie, 'De Brie' (n. 31 above), pp. 308-10. MS Paris, Bibliothèque nationale de France, Grec 2684, is a copy of Homer's Illiad with de Brie's ex-libris; manuscripts of de Brie's own works can be found in P. O. Kristeller, Iter Italicum: A Finding List of Uncatalogued or Incompletely Catalogued
} 
not been well served by the hand of time. Many of de Brie's letters to Erasmus, for instance, survived in the so-called Burscher Sammlung of Erasmus's letters held at Leipzig University Library. This manuscript was apparently destroyed in the Second World War, but thankfully after it had been seen by Percy and Helen Allen for their edition of Erasmus's correspondence. ${ }^{37}$

Among the limited body of texts to survive from de Brie's hand, there is however one manuscript relevant to our purposes. MS Wrocław, University Library, R 254, contains a letter from Germain de Brie to Erasmus. ${ }^{38}$ As P. S. Allen noted, the main text of this letter is in the hand of a secretary, but the final six lines are in Germain de Brie's autograph, a claim that can be supported by comparison with another example of de Brie's hand preserved in Basel. ${ }^{39}$ As can be seen from the figures printed below, Germain de Brie's hand matches that responsible for the bulk of the Latin annotations to the Wolfenbüttel manuscript of Chrysostom's Homilies on Romans. And by extending this comparison into annotations where Latin and Greek are mixed, we can see that the mystery hand responsible for the main part of the Greek annotations to the Wolfenbüttel manuscript is equally to be identified with Germain de Brie. ${ }^{40}$

The Greek manuscript of Chrysostom's Homilies on Romans that de Brie received from Erasmus is therefore to be identified with the manuscript of these homilies now in Wolfenbüttel. The story of its passage from Blois to Wolfenbüttel can only be partially reconstructed. Due to silence in Erasmus's letters, it is not yet clear whether the manuscript was returned to Erasmus before his death in 1536, or whether de Brie kept it until his own death in 1538. Guard pages manufactured in Leiden in 1573 imply that the manuscript was in the Low Countries towards the end of the sixteenth century. ${ }^{41}$ The manuscript was later acquired from an unknown source by the bibliophile courtier Marquard Gude (1635-1689), whose son Peter sold it, with the rest of his father's manuscripts, to Duke Anton Ulrich of Braunschweig-Wolfenbüttel, in a deal partially facilitated by the ducal librarian G. W. Leibniz. The manuscript arrived in Wolfenbüttel in 1710 , and has been there ever since. ${ }^{42}$

Footnote 36 (continued)

Humanistic Manuscripts of the Renaissance in Italian and Other Libraries, 6 vols, Leiden, 1963-1996, ad indicem.

37 The 'Burscher Sammlung' was a single manuscript, classmark MS Leipzig, Universitätsbibliothek, $0331^{\mathrm{m}}$. See D. Döring, Katalog der Handschriften der Universitäts-Bibliothek Leipzig, I.2, Wiesbaden, 2002, p. 31.

38 Letter 1733: Germain de Brie to Erasmus, Gentilly, 11 August 1526, in Erasmus, Opus epistolarum (n. 12 above), VI, pp. 376-8.

39 MS Basel, Universitätsbibliothek, Erasmuslade C 9.

40 See Figure 3 below.

41 Griechische Handschriften und Aldinen (n. 15 above), p. 102.

42 The manuscript is the second of the Greek codices listed in the auction catalogue of Gude's library, Bibliotheca exquisitissimis libris ... et MSS. codicum ... a viro illustri domino Marquardo Gudio ... congesta, Hamburg, 1706, p. 521; for the later history of Gude's manuscripts, see B. Lesser, 'Longe maximum vero Bibliothecae Augustae ornamentum: Zur Geschichte und Katalogisierung der Codices Gudiani in Wolfenbüttel', in Retter der Antike: Marquard Gude (1635-1689) auf der Suche nach den Klassikern, Wiesbaden, 2016, pp. 443-516. 
Interesting though the manuscript's later movements are, what matters most for present purposes are its sixteenth-century contents. This manuscript represents not only the best witness to Erasmus's text of the Homilies on Romans, but also the copy on which Germain de Brie based his Latin translation of this work. Having such an immediate witness to de Brie's editorial strategies is valuable. De Brie was among the foremost philologists of the early sixteenth century, deftly using textual criticism against the patristic scholarship of Johannes Oecolampadius and the patriotic poetry of Thomas More. ${ }^{43}$ It is to the theme of de Brie's editing and translation of the Homilies on Romans that we now turn.

\section{Germain de Brie's Editing and Translation of the Homilies on Romans}

Germain de Brie's annotations exist in several layers on the Wolfenbüttel manuscript. They are present in different inks, and sometimes amend earlier notes made in his hand. The manuscript moreover contains a variety of editorial signs, such as dashes and stars. This suggests that de Brie read the manuscript of Chrysostom's Homilies on Romans repeatedly and intently, an impression confirmed in his letters to Erasmus and the prefatory material to his 1533 Latin edition of the first eight of these homilies. ${ }^{44}$ In the same letter of 8 November 1530 that acknowledged receipt of the manuscript of the Homilies on Romans, de Brie wrote that he would send Erasmus a translation of Chrysostom's introductory homily and some other drafts to show his willingness to undertake the task. ${ }^{45}$ However, de Brie characteristically attached caveats to this promise. He complained that he was mired in court business, and worried lest the homilies contain knots that would prove harder to untie than those that he had yet encountered. ${ }^{46}$ These concerns soon materialized. De Brie claimed in a preface to the 1533 edition that he had repeatedly read the manuscript of the Homilies on Romans, finding it so corrupt that not even Aristarchus - the proverbial philologist of antiquity — but only Chrysostom himself might have a chance of correcting it. ${ }^{47}$ Having edited the work as far as possible, and marked uncertain places with critical signs, de Brie therefore determined to wait for another exemplar, which he hoped would come from Rome through the mediation of cardinal Agostino Trivulzio. ${ }^{48}$ But it was at that point that 'Verona extended its hand'. Through the Parisian scholar Philippe Montanus, de Brie acquired a copy of the complete Greek

\footnotetext{
${ }^{43}$ For the conflict with Oecolampadius, see the prefatory material to de Brie's Divi Ioannis Chrysostomi liber contra gentiles, Babylae Antiocheni episcopi ac martyris vitam continens...contra Ioannis Oecolampadii translationem, Paris, 1528; for that with Thomas More, see The Complete Works of St. Thomas More, III.2, New Haven and London, 1984, pp. 22-32 and 429-659.

44 Chrysostom, In Epistolam Divi Pauli (n. 10 above).

45 Letter 2405, in Erasmus, Opus epistolarum (n. 12 above), IX, p. 81.

46 Ibid., p. 81.

47 Chrysostom, In Epistolam Divi Pauli (n. 10 above), p. 11: '[Q]uae [loca] sine dubio in tuo codice sic uiciata, mendosaque erant, ut ad ea restituenda non alio Aristarcho, quam ipsomet Chrysostomo autore opus esset.'

48 Ibid., pp. 11-12.
} 
edition of Chrysostom's homilies on the Pauline epistles, printed in 1527 in Verona under the patronage of the bishop of that city, Gian Matteo Giberti. ${ }^{49}$

Having obtained this second exemplar, de Brie wrote in his preface, he set out to correct the corrupt places that he had found in the manuscript sent to him by Erasmus. ${ }^{50}$ Once more, the claims in de Brie's letters agree with his annotations to the Homilies on Romans. From the first eight of these homilies in the Wolfenbüttel manuscript, I have found 29 examples where passages marked with critical signs are accompanied by variant readings that match the Verona edition. ${ }^{51}$

If we were to rest there, we might get the impression that Germain de Brie was scrupulously committed to the editing of texts by collation. This, however, is not the complete picture of de Brie's editing. Further aspects are exposed once we compare the Wolfenbüttel manuscript with de Brie's 1533 Latin translation of the first eight of the Homilies on Romans. Here, we can see that places highlighted by de Brie with a critical mark but left blank in the Wolfenbüttel manuscript occasionally conform to the Verona edition when back-translated from his Latin version. For instance, on folio $22^{\mathrm{r}}$ of the Wolfenbüttel manuscript, we find that de Brie has noted the word ' $\alpha \dot{\tau} \mathrm{\alpha} \lambda \varepsilon i \alpha \varsigma^{\prime}$ for attention. This was left blank, but in his version of Chrysostom, de Brie translated incredulitatis, silently following the reading ' $\alpha \dot{\tau} \mathrm{\sigma} \sigma i \alpha \varsigma^{\prime}$ ' in the Verona edition. ${ }^{52}$ This indicates that de Brie sometimes relied on the Verona edition to a greater degree than his annotations suggest. However, other techniques of editing are uncovered when his translation and his Greek exemplars are compared. In one passage, de Brie opted for the singular uiro, 'man' (translating ' $\alpha \nu \delta \rho o ́ \varsigma$ ' and

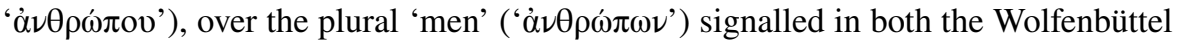
manuscript and the Verona edition. ${ }^{53}$ Sometimes, the two methods of ope codicum and ope ingenii came together. De Brie emended one passage of the Wolfenbüttel

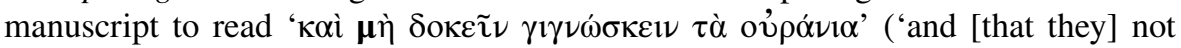
seem to know heavenly things'). ${ }^{54}$ This differs from the Verona edition, which reads

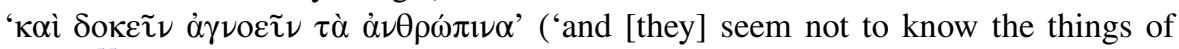
men'). ${ }^{55}$ But in his translation, de Brie rendered this passage as 'ut ne uideantur coelestia ignorare' ('lest they seem not to know heavenly things'). ${ }^{56}$ This is a transla-

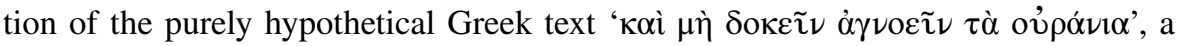

\footnotetext{
49 Ibid., pp. 6 and 11: '[E]n nobis tandem Verona manum porrexit suam ... nunciat ille [Montanus] nobis hic tandem uenire idem illud Chrysostomi opus, Veronae typis Graecis excusum. cuius mihi copiam fieri quum magnopere me cupere indicassem, ecce tibi Montanus e uestigio ad me, opus ipsum perfert.' The edition is John Chrysostom, In omnes Pauli apostoli epistolas accuratissima vereque aurea et divina interpretatio, Verona, 1529.

${ }^{50}$ Chrysostom, In Epistolam Divi Pauli (n. 10 above), p. 11.

51 I have found such examples in the following folios: $6^{\mathrm{r}}, 6^{\mathrm{v}}, 7^{\mathrm{r}}, 9^{\mathrm{r}}, 12^{\mathrm{r}}, 17^{\mathrm{v}}, 18^{\mathrm{v}}, 19^{\mathrm{r}}, 19^{\mathrm{v}}, 20^{\mathrm{r}}, 22^{\mathrm{r}}, 23^{\mathrm{v}}$, $24^{\mathrm{v}}, 28^{\mathrm{v}}, 29^{\mathrm{r}}, 30^{\mathrm{v}}, 34^{\mathrm{r}}, 35^{\mathrm{v}}, 39^{\mathrm{v}}, 40^{\mathrm{r}}, 47^{\mathrm{v}}, 51^{\mathrm{r}}, 55^{\mathrm{v}}, 58^{\mathrm{v}}, 59^{\mathrm{r}}, 59^{\mathrm{v}}, 65^{\mathrm{r}}, 71^{\mathrm{v}}, 72^{\mathrm{v}}$.

52 Chrysostom, In Epistolam Divi Pauli (n. 10 above), p. 63; id., In omnes Pauli apostoli epistolas accuratissima vereque aurea et divina interpretatio (n. 49 above), $10^{\mathrm{r}}$.

53 Ibid., p. 87; MS Wolfenbüttel, Herzog August Bibliothek, Gud. gr. $2^{\circ}$ 10, fol. 30 ; Chrysostom, In omnes Pauli apostoli epistolas (n. 49 above), fol. $14^{\mathrm{r}}$.

54 MS Wolfenbüttel, Herzog August Bibliothek, Gud. gr. $2^{\circ} 10$, fol. $21^{\mathrm{v}}$.

55 Chrysostom, In omnes Pauli apostoli epistolas (n. 49 above), $10^{\mathrm{r}}$.

56 Chrysostom, In Epistolam Divi Pauli (n. 10 above), p. 62.
} 
reading that de Brie constructed on the basis of the Wolfenbüttel manuscript, adding the word ' $\alpha \gamma \nu$ $\gamma \tilde{\imath} \nu$ ' from the Verona edition, and the negation ' $\mu$ ' from his own conjecture.

De Brie had arguably declared the necessity for such hybrid passages in the prefaces to his Latin translation of the Homilies on Romans. In his opening letter to Erasmus, de Brie complained that he owned no totally reliable Greek exemplar of these homilies. Bitter experience had shown him that not just the manuscript, but also the Verona text was corrupt. De Brie continued to hope that he could solve this problem by obtaining a manuscript from Rome through the auspices of cardinal Trivulzio. ${ }^{57}$ There is no evidence that this came to pass, but there was one other source of potential help available to de Brie. The Frenchman never declared the extent to which he drawn on the work of one correspondent: that of Erasmus. This is despite the fact that, as we have seen, Erasmus had studied and even translated passages from Chrysostom's Homilies on Romans in his Annotations of 1527.

We can see that Germain de Brie drew on Erasmus's scholarship in his study of Chrysostom's Homilies on Romans. Here, we can take as an example the reading of Romans 1:27 preserved in the texts available to de Brie. The reading of this passage in the Wolfenbüttel manuscript is 'ó $\mu$ oí $\omega \varsigma$ $\delta \varepsilon ', 58$ which de Brie has marked for correction to 'ó $\mu$ oí $\omega \varsigma \tau \varepsilon$ '. Nonetheless, the Verona edition cannot have provided this

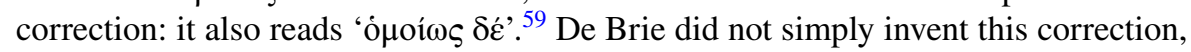
however. His preferred reading of 'ó $\mu$ oí $\omega \varsigma \tau \varepsilon$ ' is that which we find in Erasmus's edition of the New Testament, and de Brie's Latin version equally follows Erasmus's translation ('similiterque') over the readings of both the Wolfenbüttel manuscript and the Verona edition, which would have given a Latin text in line with the Vulgate ('similiter autem'). ${ }^{60}$

When placed in a broader context, de Brie's editing of Romans 1:27 is informative about the nature of humanist Bible scholarship in the early Reformation. Fifteenth-century translators of Chrysostom such as Lelio Tifernate had translated Chrysostom's Greek even where it gave a Latin reading different from the received Vulgate text. ${ }^{61}$ By contrast, de Brie not only followed Erasmus's Latin version of the New Testament, but even emended the Greek readings of his manuscript to follow the Dutchman's version. In his adherence to one version of the Bible at least, it has to be asked whether de Brie was any more critical than later Catholic scholars who faithfully followed the Vulgate when presenting Bible passages cited by the Greek Fathers. Like the edition attributed to Jerome, it appears that Erasmus's version of

\footnotetext{
57 Ibid., p. 11.

58 MS Wolfenbüttel, Herzog August Bibliothek, Gud. gr. $2^{\circ} 10$, fol. $27^{\mathrm{v}}$.

59 Chrysostom, In omnes Pauli apostoli epistolas (n. 49 above), fol. $13^{\mathrm{r}}$.

60 Desiderius Erasmus, Opera omnia ... Ordinis sexti, tomus tertius, ed. A. J. Brown, Leiden, 2004, pp. $32-3$.

61 Quedamque de sacris mutuata scripturis iuxta graecam edicionem traduxi. quae tametsi a nouissima nostra quandoque discrepent. consilium tamen non fuit eadem a greca dimouere sentencia, quo a Crisostomo quae disputantur clarius conuenienciusque consentiant', quoted in U. Jaitner-Hahner, Humanismus in Umbrien und Rom: Lilius Tifernas, Kanzler und Gelehrter des Quattrocento, II, Baden-Baden, 1993, p. 474.
} 
the New Testament inspired reverence in some scholars, at least those who were personally and intellectually close to the Dutchman.

In Greek and Latin, de Brie's editing and translation of Chrysostom's Homilies on Romans drew on Erasmus's Bible scholarship. But as just noted, Erasmus had also translated parts of Chrysostom's Homilies on Romans in his Annotations of 1527. In order to evaluate whether de Brie followed the Dutchman in this respect, we can explore a passage where Erasmus provided a Latin translation of Chrysostom's Greek. One such passage is Chrysostom's exposition of Romans 4:1:

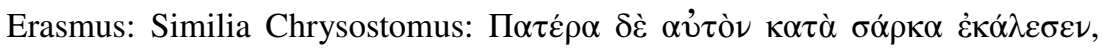

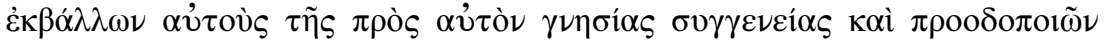

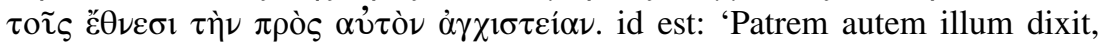
excludens eos a vera Abrahae cognatione simulque viam aperiens gentibus ad affinitatem Abrahae consequendam'. ${ }^{2}$

De Brie: Ipsum porro patrem secundum carnem nominauit, hac ratione ipsum depellens ab ea germana cognatione, quae illi cum eis intercederet, ac gentibus quasi uia strata indicans propinquitatem, quam cum illo haberent. ${ }^{63}$

In syntax, vocabulary and even meaning, there are significant differences in the way that Erasmus and de Brie rendered this passage into Latin. In part, these differences can be explained by the Greek text used by each scholar. In this passage, de Brie at times preferred readings from the Verona edition of Chrysostom's homilies, whereas Erasmus, lacking this text, was reliant upon readings in his manuscript that are preserved in the Wolfenbuittel copy. De Brie translated 'hac ratione ipsum depellens ab ea germana cognatione, quae illi cum eis intercederet', following the Verona edition

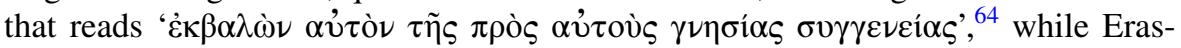
mus translated 'excludens eos a vera Abrahae cognatione' as his manuscript read

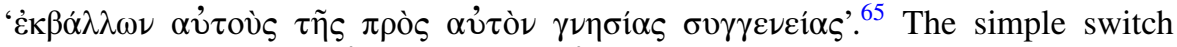
between the pronouns $\alpha$ v่ óv (he) and $\alpha$ v่oús (they) made all of the difference for whether Abraham (de Brie) or the Jews (Erasmus) were excluded from the spiritual understanding that was the focus of the sentence.

Here, we can see that de Brie exercised an editorial liberty with the text of Chrysostom that differed from his consistent use of Erasmus's version of the New Testament. We saw above that de Brie was willing to follow Erasmus's text of the Bible even where this meant editing the readings of his Greek text. He was apparently less concerned about following Erasmus's patristic scholarship, happy to use a Greek text of Chrysostom that read differently to that used by Erasmus, and failing to follow Erasmus's translations of Chrysostom even where their Greek texts agreed, as in the final part of the example quoted above. De Brie's translations of

\footnotetext{
62 Erasmus, Opera omnia (n. 3 above), p. 114.

63 Chrysostom, In Epistolam Divi Pauli (n. 10 above), p. 177.

${ }^{64}$ Chrysostom, In omnes Pauli apostoli epistolas (n. 49 above), fol. $30^{\mathrm{r}}$.

65 MS Wolfenbüttel, Herzog August Bibliothek, Gud. gr. $2^{\circ} 10$, fol. $62^{r}$.
} 
Chrysostom in fact never correlate with those given by Erasmus in his 1527 edition of the Annotations. ${ }^{66}$

\section{Erasmus and Chrysostom in the 1535 Edition of the Annotations}

By 1533, two different versions of Chrysostom's Homilies on Romans were therefore circulating in Latin, one in Erasmus's Annotations, and another in the translation of Germain de Brie. Erasmus soon had an opportunity to take into account his friend's scholarship. In 1535, a new edition of the Annotations was printed by Froben in Basel.

Erasmus added more citations of Chrysostom to the 1535 edition of the Annotations than he had to the 1527 edition. Commonly, these were long quotes of Chrysostom in Latin and Greek, added as a result of Erasmus's polemic with the Louvain Franciscan Frans Titelmans, whose 1529 commentary on Romans had attacked Erasmus's understanding of the Bible. ${ }^{67}$ Unfortunately, no correspondence between de Brie and Erasmus survives after de Brie's preface to the 1533 translation of the Homilies on Romans. This makes it impossible to know when or whether Erasmus was able to read de Brie's translation, but it is likely that Erasmus was quickly aware of this edition, printed as it was by Froben in Basel. Despite these favourable circumstances, none of the citations added by Erasmus to the 1535 edition correspond with Germain de Brie's translation. ${ }^{68}$ Much as his friend had done in 1533, Erasmus preferred to rely on his own patristic scholarship.

Even if Erasmus continued to translate Chrysostom afresh despite the existence of de Brie's edition, in one sense the 1535 edition of the Annotations marks a change in Erasmus's knowledge of Chrysostom's text of the Homilies on Romans. In one passage of the 1535 Annotations, Erasmus referred to a reading in the Verona edition of Chrysostom's Homilies on Paul. ${ }^{69}$ We can assume therefore that Erasmus had access to the Verona edition by 1535 , a potentially more important contribution to his scholarship than de Brie's Latin translation of the Homilies on Romans. Whereas Erasmus was dependent on the Greek text of his manuscript for the 1527 Annotations, in 1535 he could collate this text with the Verona edition.

To explore how Erasmus made use of these resources, we can take as our example a passage added to the 1535 Annotations that Greta Kroeker signalled as important to Erasmus's evolving theology of free will and grace. ${ }^{70}$ The passage in question is a gloss on Romans 5:1. The Vulgate translated this verse as 'Iustificati igitur ex

\footnotetext{
${ }^{66}$ Compare the translations of Chrysostom in Erasmus, Opera omnia (n. 3 above), pp. 42 and 54 with Chrysostom, In Epistolam Divi Pauli (n. 10 above), pp. 31 and 33 respectively.

${ }^{67}$ Frans Titelmans, Collationes quinque super epistolam ad Romanos, Antwerp, 1529.

68 In addition to the places signalled in n. 63, compare the translations of Chrysostom in Erasmus, Opera omnia (n. 3 above), pp. 64 and 84-6 with Chrysostom, In Epistolam Divi Pauli (n. 10 above), pp. 53 and 95 respectively.

69 Erasmus, Opera omnia (n. 3 above), p. 330. 'Quanquam aeditio Veronensis habet tria: $\alpha \dot{\alpha} \varepsilon \dot{\varepsilon} \theta \nu \varepsilon \nu$,

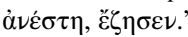

70 Kroeker, Erasmus in the Footsteps (n. 2 above), pp. 84-5.
} 
fide, pacem habeamus erga deum' ('Justified therefore by faith, let us have peace towards God'). In his own translation, Erasmus however preferred 'pacem habemus erga deum' ('we have peace towards God'). This preference for the indicative habemus ('we have') over the subjunctive habeamus ('let us have') made peace towards God flow unproblematically from justification, emphasizing the power of grace in line with Erasmus's changing theology of salvation. Erasmus's citation of Chrysostom on this verse is revealing:

In Chrysostom the text [cited] has '̌ $\chi \omega \mu \varepsilon \nu$ 'let us have,' and likewise the commentary; but that this is a mistake made through the carelessness of copyists is

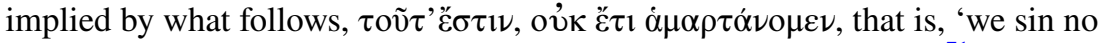
more', where [the copyist] has not changed the omicron [to omega]. ${ }^{71}$

Erasmus therefore adduced Chrysostom in support of the indicative over the subjunctive form of the contentious verb in this verse. His argument rested on the assertion that Chrysostom really wrote "̌ $\chi 0 \mu \varepsilon \nu$ ('we have'), but that careless scribes had changed this word to "' $\chi \omega \mu \varepsilon \nu$ ('let us have'). Yet the foundations on which Erasmus constructed this argument were remarkably shaky. He preferred to overlook two clear examples of the subjunctive " $₹ \omega \omega \mu \nu \nu$ ('let us have') in favour of a single indicative use of a totally different word, $\alpha \mu \alpha \rho \tau \alpha \dot{\alpha} \nu \rho \mu \varepsilon \nu$ ('we sin'). Indeed, Erasmus's contention that Chrysostom read $\alpha \mu \alpha \rho \tau \alpha \dot{\alpha} \nu \mu \varepsilon \varepsilon \nu$ was not totally correct. Erasmus's manuscript text of Chrysostom - preserved in the Wolfenbüttel copy - indeed presents this passage as Erasmus claimed it read, in the indicative. ${ }^{72}$ This was all Erasmus had in 1527, but as we have just seen, in 1535 Erasmus also had access to the Verona edition of Chrysostom's Homilies on Romans. If we pursue Chrysostom's exegesis of Romans 5:1 into this edition, we find a different reading. There, we see no use of the indicative $\alpha \mu \alpha \rho \tau \alpha \dot{\alpha} \nu o \mu \varepsilon \nu$ (we sin [no more]), but rather the subjunctive $\dot{\alpha} \mu \alpha \rho \tau \alpha \dot{\alpha} \nu \omega \mu \varepsilon \nu$ ('let us sin [no more]'). ${ }^{73}$

In determining which readings of the Greek of Chrysostom's Homilies on Romans to use in his 1535 revision of the Annotations, Erasmus was provided with a faculty that he previously lacked: choice. He could choose whether to follow his manuscript, or the Verona edition. In his citation of Chrysostom's commentary of Romans 5:1, Erasmus opted to follow his manuscript. But he did so against overwhelming odds, clinging to the one example of the indicative in either text over the many examples of the subjunctive in both his manuscript and the Verona edition. We do not have to search too far for why this was so. Erasmus fought for Chrysostom as a witness to c $\chi 0 \mu \varepsilon \nu$ as it was his preferred reading of this verse, making as it did a stronger argument for the power of grace. In this example at least, theology guided Erasmus's philology.

\footnotetext{
71 Erasmus, Annotations on Romans (n. 17 above), p. 127.

72 MS Wolfenbüttel, Herzog August Bibliothek, Gud. gr. $2^{\circ} 10$, fol. $74^{\mathrm{r}}$.

73 Chrysostom, In omnes Pauli apostoli epistolas (n. 49 above), fol. $35^{\mathrm{r}}$.
} 


\section{Conclusion}

This article has attempted to reconstruct the puzzle of Erasmus's use of Chrysostom's Homilies on Romans. This attempt will remain partially incomplete. The loss of the Burscher Sammlung of Leipzig University Library, for instance, has deprived us not only of the autograph letters between Erasmus and Germain de Brie, but also four folios on which Erasmus wrote his observations about de Brie's translation of the Homilies on Romans. ${ }^{74}$ But even in the state of current research, it is possible to reach some overall conclusions.

The first conclusions concern the discovery of Wolfenbüttel: Herzog August Bibliothek, Gud. gr. $2^{\circ} 10$ as an important witness to the reception of John Chrysostom in the early Reformation. By identifying the hand of the main annotator with Germain de Brie, we can for the first time explore the behind-the-scenes work of this critic and translator. This is not to suggest that de Brie's annotations to the Wolfenbüttel manuscript offer a complete picture of his editorial work, however. By comparing the emendations to the Wolfenbüttel manuscript with de Brie's Latin translation, we saw that this manuscript is only a partial witness to the editorial decisions that he made. Many readings from the Verona edition that de Brie preferred in his translation are not noted on the pages of this manuscript. For this reason, the principal utility of the Wolfenbüttel manuscript may not be its status as the working text for de Brie's translation of the Homilies on Romans. Instead, its primary value rests in the fact that it is an apparently accurate copy of Erasmus's now-lost manuscript of the Homilies on Romans, providing an indispensable witness to Erasmus's Greek text of this work of Chrysostom. As has already been stressed, any exploration of Erasmus's use of Chrysostom's Homilies on Romans should now refer to the Wolfenbüttel manuscript rather than later printed editions like Migne, which present a text that Erasmus had no conceivable access to. ${ }^{75}$

A second set of conclusions extends beyond the Wolfenbüttel manuscript of Chrysostom's Homilies on Romans. There is now a growing stock of studies about sixteenth-century patristic scholarship, much of which has been concerned with the interaction between different confessions. ${ }^{76}$ The history of Chrysostom's Homilies on Romans however highlights another area of concern. Germain de Brie and Erasmus were Catholic scholars, and moreover good friends working in close communication. Nonetheless, there was a striking lack of collaboration in their patristic scholarship. While de Brie was conscientious in following Erasmus's edition of the New

\footnotetext{
74 See the introduction to Letter 2359: Erasmus to Christoph von Stadion, Freiburg, 5 August 1530, in Erasmus, Opus epistolarum (n. 12 above), IX, pp. 3-4.

75 The Migne text is based on Savile's 1613 edition, itself based on the 1596 Heidelberg and 1529 Verona editions, with successive emendations against manuscript sources alleged in each case. For Migne's sources for the Homilies on Romans, see the notes to Patrologia cursus completes ... series Graeca prior (n. 18 above), cols 392-3; for Savile's, see John Chrysostom, Opera Graece, VIII, Eton, 1613, cols 225-6.

${ }^{76}$ For two different approaches to this question, see P. Polman, L'élément historique dans la controverse religieuse du XVIe siècle, Gembloux, 1932, and I. Backus, Historical Method and Confessional Identity in the Era of the Reformation (1378-1615), Leiden, 2003.
} 
Testament, he completely ignored his friend's translations of Chrysostom's Homilies on Romans. Erasmus did the same, in 1535 preferring to translate Chrysostom anew rather than relying on de Brie's 1533 edition. In the early Reformation, there was as such a diversity of patristic scholarship within as well as between confessions, and even between the closest friends and collaborators.

A third and final set of conclusions concerns Erasmus himself. In patristics, Erasmus's contributions to learning have been typically assessed in the history of textual scholarship. Arguments have tended to concern the degree to which he was indebted to classical and medieval precedents, or a true break from earlier traditions of criticism. ${ }^{77}$ From this perspective, Erasmus has sometimes been feted as a critic whose commitment to truth and historicity were far in advance of his time. ${ }^{78}$ But in his claim that Chrysostom was a witness to his preferred reading of Romans 5:1, Erasmus's editing of Chrysostom was typical of the sixteenth century. It was no less ideological than the patristic scholarship of a Reformed scholar like Johannes Oecolampadius, or of Catholic theologians during the Council of Trent. When good criticism is equated with fidelity to the text, Erasmus's partiality for certain readings can only be dismissed as a failure in the longer narrative of textual criticism. ${ }^{79}$ There may be some general truth in that, but when our concern is with history, unwillingness to engage with the motivations of historical actors implied by this method suggests that a different narrative may be needed. As we become more aware of the power of religion in early modern scholarship, it may be worth reflecting on whether religious belief was as important in Erasmus's textual criticism as it was for many of his contemporaries and successors. Indeed, if we approach Erasmus as an exceptionally able philologist using his skills and resources to support a specific set of beliefs, his editing Chrysostom's Homilies on Romans becomes an informative window into his scholarship, rather than an unfortunate lapse of objectivity that is best condemned or ignored. It may even make the case for incorporating Erasmus into a longer history of confession in the republic of letters, the origins of which the best recent work has only traced to the end of the sixteenth century. ${ }^{80}$

\footnotetext{
77 A good introduction to these debates is N. Naquin, "'On the Shoulders of Hercules": Erasmus, the Froben Press and the 1516 Jerome Edition in Context', PhD diss., Princeton University, 2013, pp. xxivxli.

${ }^{78}$ Ibid., pp. xxvi-xxxi.

79 This equivalence between partiality and failure, if in regard to Erasmus's biographies, is seen for instance in J. B. Maguire, 'Erasmus' Biographical Masterpiece: Hieronymi Stridonensis Vita', Renaissance Quarterly, 26, 1973, pp. 265-73 (271).

${ }^{80}$ N. Hardy, Criticism and Confession: The Bible in the Seventeenth Century Republic of Letters, Oxford, 2017.
} 


\section{Figures:}

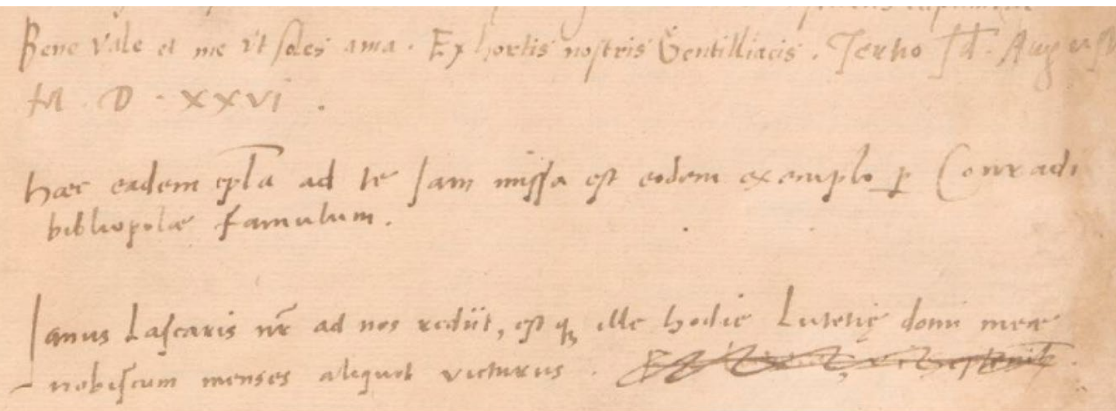

1. Germain de Brie's autograph additions to a letter to Erasmus (letter 1733, 11 August 1526). See n. 38 above. MS Wroclaw, University Library, R 254 fol. $31^{\mathrm{r}}$.

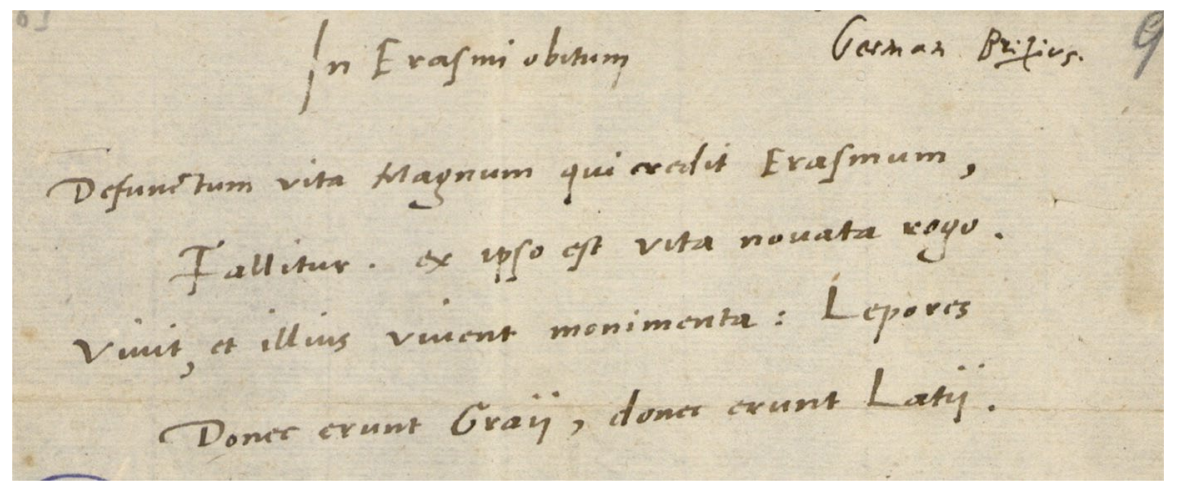

2. An autograph poem by Germain de Brie to mark the death of Erasmus. See n. 39 above. MS Basel, Universitätsbibliothek, Erasmuslade C 9. 


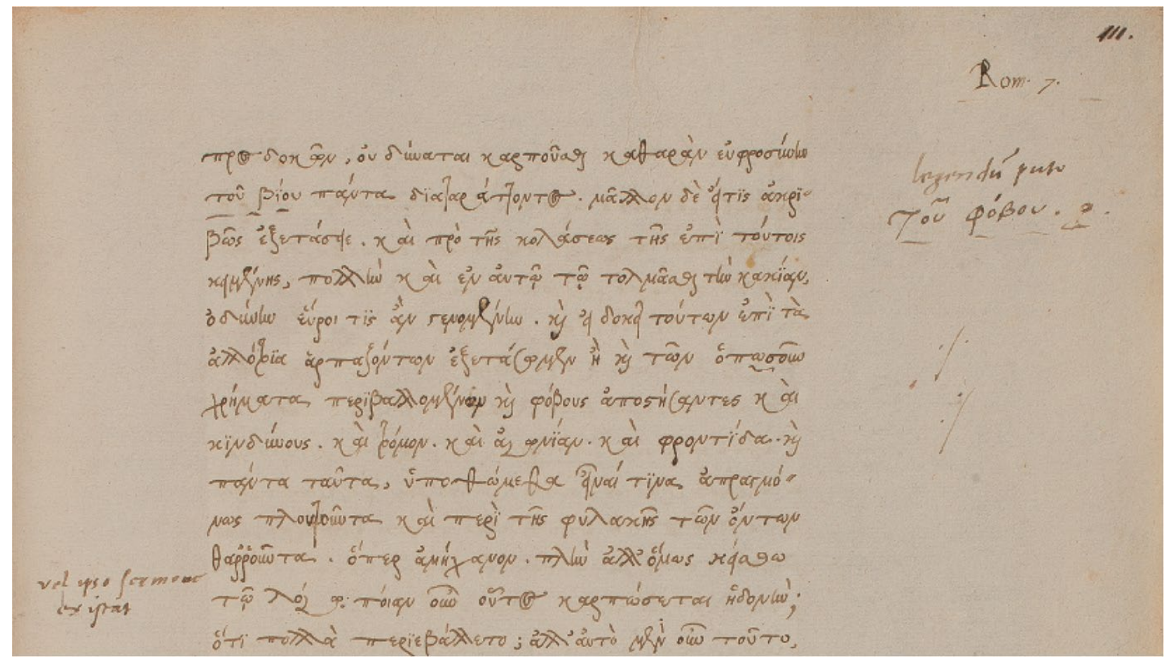

3. Germain de Brie's hand in the margins of MS Wolfenbüttel, Herzog August Bibliothek, Gud. gr. $2^{\circ} 10$, fol. $111^{r}$.

Open Access This article is distributed under the terms of the Creative Commons Attribution 4.0 International License (http://creativecommons.org/licenses/by/4.0/), which permits unrestricted use, distribution, and reproduction in any medium, provided you give appropriate credit to the original author(s) and the source, provide a link to the Creative Commons license, and indicate if changes were made.

Publisher's Note Springer Nature remains neutral with regard to jurisdictional claims in published maps and institutional affiliations. 